\title{
Serum intercellular adhesion molecule- 1 levels in chronic hepatitis C: association with disease activity and response to interferon $\alpha$
}

\author{
K T Nouri-Aria, J Koskinas, C J Tibbs, B C Portmann, Roger Williams
}

\begin{abstract}
Soluble intercellular adhesion molecule-1 (sICAM-1) is probably released from a variety of cells, including leukocytes and endothelial cells at sites of inflammation or in the circulation, and serum levels may therefore be used to give an indication of immune activation and inflammatory processes. In the present study, an ELISA was used to measure serum ICAM-1 levels in 43 patients with chronic hepatitis $\mathbf{C}$ and these were correlated with histological changes in the liver and the response to interferon $\alpha$ treatment. Serum ICAM-1 levels were significantly higher in patients with chronic hepatitis $\mathbf{C}$ infection than in normal subjects and correlated positively with the grade of histological activity, in particular the degree of portal, periportal, and lobular inflammation, but not with the presence of lymphoid aggregates. There was also a weak but significant positive correlation between SICAM-1 and serum aspartate aminotransferase activities, and SICAM-1 levels were substantially greater in patients with than those without cirrhosis. Serum ICAM-1 levels fell significantly in 11 responders out of 19 patients treated with interferon $\alpha$, whereas levels remained unchanged in the non-responder group. sICAM-1 levels correlate with the clinical status of patients with chronic hepatitis $\mathbf{C}$ infection and fall with successful interferon treatment.
\end{abstract}

(Gut 1995; 36: 599-603)

Keywords: intercellular adhesion molecule-1, hepatitis $\mathrm{C}$ infection, interferon $\alpha$, disease activity.

Intercellular adhesion molecule-1 (ICAM-1) (CD54), a member of the immunoglobulin (Ig) supergene family, is expressed on the surface membrane of cells of multiple lineage at sites of inflammation. ${ }^{1}$ ICAM-1 comprises five extracellular Ig-like domains, a single transmembrane region, and a short cytoplasmic tail ${ }^{2}$

TABLE I Clinical, serological, and histological characteristics of patients with chronic hepatitis $C$ virus infection. Values are mean (SD)

\begin{tabular}{llccl}
\hline Disease activity & Age $(y)$ & $M / F$ & AST & Cirrhosis \\
\hline Severe hepatitis $(\mathrm{n}=7)$ & $47 \cdot 8(11)$ & $6 / 1$ & $106(43)$ & 7 \\
Moderate hepatitis $(\mathrm{n}=14)$ & $41 \cdot 4(13)$ & $12 / 2$ & $62(21)$ & 8 \\
Mild hepatitis $(\mathrm{n}=22)$ & $30 \cdot 8(4)$ & $16 / 6$ & $46(9)$ & 4
\end{tabular}

$\mathrm{M} / \mathrm{F}=$ male/female, AST $=$ aspartate transaminase. and is a natural ligand for at least two members of the CD18 family of leukocyte integrin adhesion molecules: lymphocyte function associated antigen-1 (LFA-1; CD11 a/CD18) and MAC-1 (CD11b/CD18). ${ }^{3}$ ICAM-1 is believed to play an important part in a variety of inflammatory and immune mediated mechanisms, including lymphocyte recruitment and targeting, antigen presentation and recognition, and lymphocyte cytotoxicity. ${ }^{4}$ Proinflammatory cytokines (for example, tumour necrosis factor $\alpha$ and interleukin 1) enhance expression of ICAM-167 and previous studies have shown that ICAM-1 is strongly expressed on hepatocytes in patients with several inflammatory disorders of the liver. A soluble form of ICAM-1 (sICAM-1), comprising the five extracellular Ig-like domains of ICAM-1, was recently detected in human serum $^{89}$ and it has been suggested that this may prove useful in the investigation, diagnosis, and therapeutic monitoring of inflammatory disorders. ${ }^{1011}$ Levels of sICAM-1 have been shown to be high in a variety of inflammatory conditions of the liver ${ }^{12} 13$ but this has not been correlated with the severity or stage of disease in patients with viral hepatitis or with response to treatment. This study investigates the relationship between sICAM-1 levels and the stage and severity of liver disease in patients with chronic hepatitis $C$, and the effect of interferon $\alpha$ treatment on these sICAM-1 levels.

\section{Methods}

Forty three patients (age range 23-72 years) with chronic hepatitis $\mathrm{C}$ virus (HCV) infection, 19 of whom had cirrhosis clearly established on histological examination, were studied (Table I). All patients were anti-HCV (UBI Inc, NY, USA) in serum or liver HCV RNA positive, or both (nested polymerase chain reaction); two patients also had a history of HBV infection. Nineteen of these patients (nine with mild, six with moderate, and the remaining four with severe hepatitis as assessed histologically) were treated with recombinant interferon $\alpha-2 b$ (IFN- $\alpha$ ) (Intron A, Schering Plough Mildenhall, Suffolk) for one year in a regimen of stepwise reduction over three months from $10 \mathrm{MU}$ three times per week to a maintenance dose of $3 \mathrm{MU}$ thrice weekly for the final nine months of treatment. Response to treatment is defined as a return to normal of serum transaminase activities, a partial response as a fall in transaminases of more than $50 \%$, and failure as no fall in transaminase. Serum ICAM-1 levels were determined in all patients before and after 
one, six, and 12 months of therapy, and in 13 patients, one year after the end of treatment. Sera from 33 age and sex matched healthy normal subjects ( 15 women, mean age $37 \pm 10$ years) were also separated and kept frozen at $-20^{\circ} \mathrm{C}$ within four hours of venesection and had not been thawed before assay for ICAM-1.

\section{MEASUREMENT OF ICAM-1 IN SERUM}

The level of serum ICAM-1 was measured using an ELISA kit (British Bio-technology Ltd, Oxford UK) as described by the manufacturer. Briefly $100 \mu \mathrm{l}$ of biotinylated antiICAM-1 and $100 \mu \mathrm{l}$ of standard or diluted samples were added to each well, precoated with monoclonal antibody to an immunoreactive epitope of human ICAM-1. They were then covered and incubated at room temperature for two hours. The well was washed three times with wash buffer and then incubated for one hour with $100 \mu l$ of streptavidin-horseradish peroxidase at room temperature. The plate was washed again and incubated with $100 \mu l$ of substrate for 10 minutes before the addition of stop solution. The optical density was determined at $450 \mathrm{~nm}$ with a correction wavelength of $620 \mathrm{~nm}$. The levels of sICAM-1 were calculated from standard curves and the results were expressed as $\mathrm{ng} / \mathrm{ml}$.

\section{NESTED POLYMERASE CHAIN REACTION}

Serum HCV RNA was detected by nested polymerase chain reaction (PCR) using primers from $5^{\prime}$ non-coding region of $\mathrm{HCV}$ genome as previously described. ${ }^{14}$ Outer primers were: JR12 (nt 1-20, 5'-GGCGACACTCCACCATAGAT-3') and JR19 (nt 197-216, 5'CGCCCAAATCTCCAGGCATT-3'), and inner primers were: JR13 (nt 35-53, 5'-GAACTACTGTCTTCACGCA-3') and JR14 (nt 141-161, 5'-GGCAATTCCGGTGTACTCACC-3'). ${ }^{15}$ To avoid false-positive results, PCR was performed with rigid adherence to the recommendations of Kowk and Higushi, ${ }^{16}$ and with appropriate positive and negative controls.

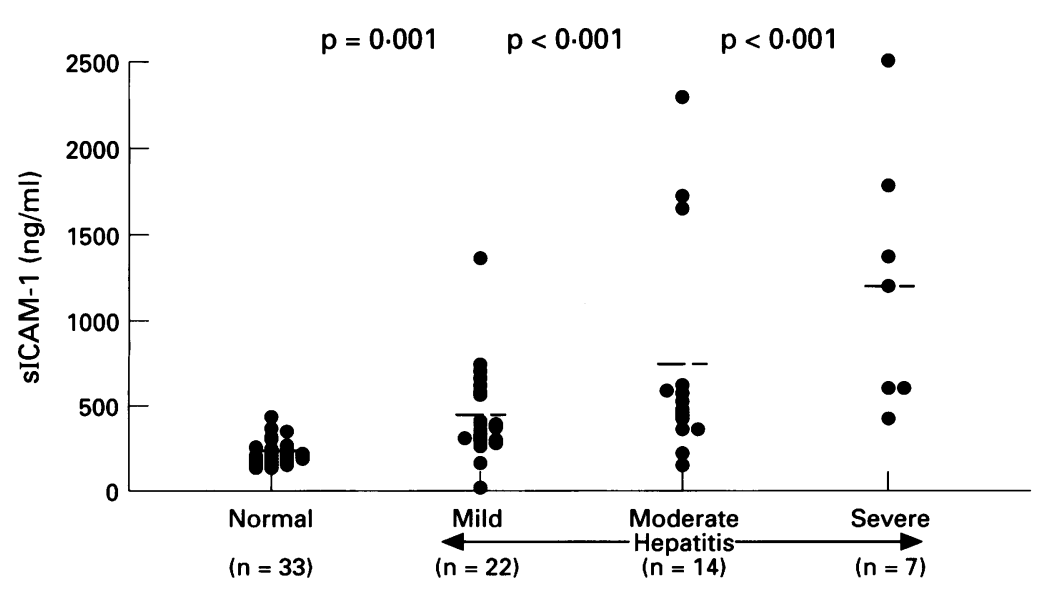

Figure 1: Serum intercellular adhesion molecule-1 (ICAM-1) values ( $\mathrm{ng} / \mathrm{ml})$ in chronic HCV infection. $p$ Values shown compared with normal subjects. Bars indicate mean sICAM-1 levels.

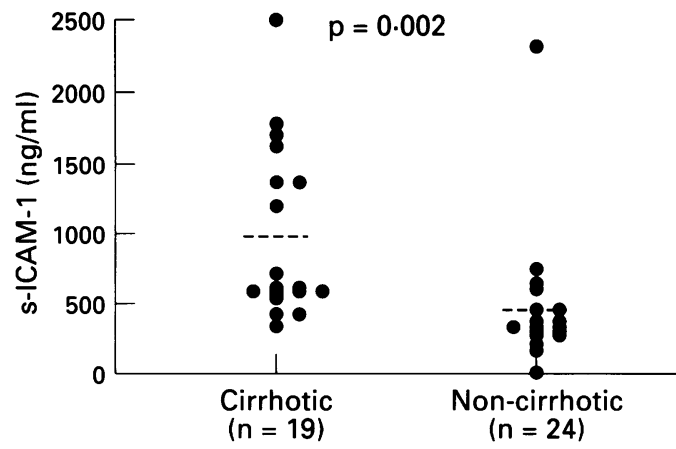

Figure 2: Serum intercellular adhesion molecule-1 (ICAM-1) values $(\mathrm{ng} / \mathrm{ml})$ in cirrhotic and non-cirrhotic patients with chronic hepatitis virus HCV infection. Bars indicate mean sICAM-1 values.

\section{STATISTICAL ANALYSIS}

Statistical significance was calculated by Mann-Whitney U test for non-parametric values. The paired $t$ test was used to analyse the effect of IFN- $\alpha$ on serum ICAM-1 levels before and after the treatment. The Spearman rank correlation coefficient was performed to evaluate the correlation between serum ICAM-1 and portal/periportal inflammation, lobular activities, lymphoid aggregates and aspartate transaminase activities.

\section{Results}

Levels of sICAM-1 were significantly greater in patients with chronic $\mathrm{HCV}$ infection. Mean (SD) values for those with mild hepatitis (439 (58) $\mathrm{ng} / \mathrm{ml}(\mathrm{p}=0.001))$, moderate hepatitis (743 (173) $\mathrm{ng} / \mathrm{ml}(\mathrm{p}<0.001))$, and severe hepatitis $(1209(283) \mathrm{ng} / \mathrm{ml}(\mathrm{p}<0.001))$ were considerably higher than values in 33 healthy subjects (220 (11) ng/ml) (Fig 1). Levels were also significantly higher in cirrhotic (937 (140)) $\mathrm{ng} / \mathrm{ml}$ than non-cirrhotic (433 (82) $\mathrm{ng} / \mathrm{ml}, \mathrm{p}=0.002$ ) patients (Fig 2). There was a positive correlation between the levels of sICAM-1 and the hepatic inflammation in the portal tracts (RS $=0.556, \mathrm{n}=43, \mathrm{p}<0.001$ ), periportal areas $(R S=0.557, p<0.001)$, and lobular activity $(R S=0.446, n=43, p=0.003)$ (Fig 3A and 3B). The presence or absence of lymphoid aggregates in the liver biopsy specimens, however, did not correlate with sICAM1 levels ( $R S=0.0686, n=43, p=0.674$ ) in patients with chronic $\mathrm{HCV}$ infection. There was also a weak but significant correlation between sICAM-1 and aspartate transaminase activities when the data were analysed for patients, irrespective of the phase of treatment ( $R S=0.476, n=102, p<0.001$ ) (Fig 3C).

Eleven patients responded to IFN- $\alpha$ treatment as defined by a return to normal of serum aspartate aminotransferase activities, six did not respond, and the remaining two showed a partial response (more than $50 \%$ reduction in activities from the pretreatment values). Overall, the mean sICAM-1 level did not change significantly with IFN- $\alpha$ treatment (575 (74) $\mathrm{ng} / \mathrm{ml}$ before and 595 (136) $\mathrm{ng} / \mathrm{ml}$ after one year of treatment $(p=N S))$. When the data were analysed separately, however, the sICAM-1 did fall in responders from 677 (112) $\mathrm{ng} / \mathrm{ml}$ before treatment to $582(153)$ at 

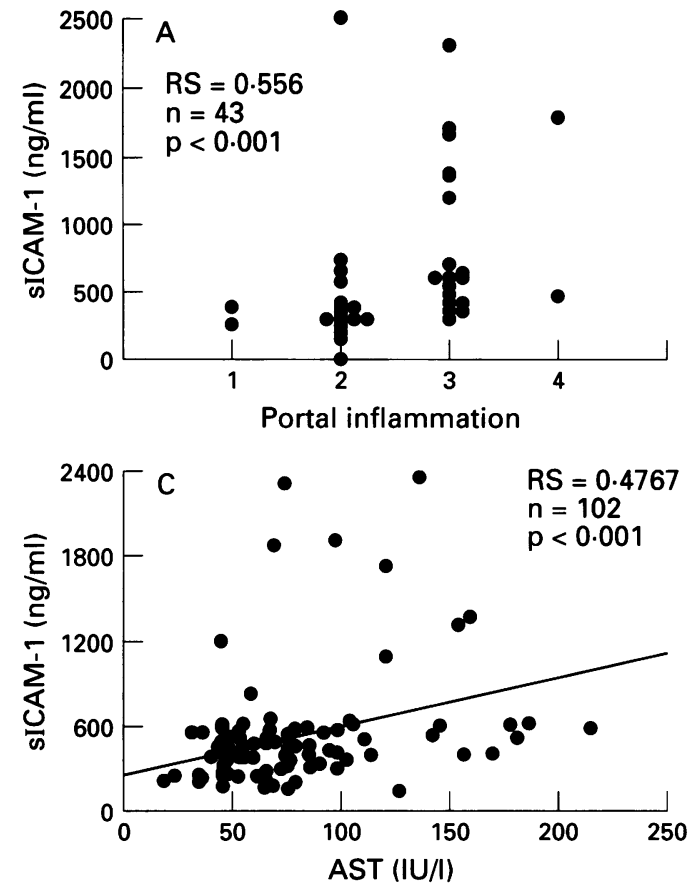

six months and $375(38) \mathrm{ng} / \mathrm{ml}$ at the end of treatment $(p=0.01)$. In non-responders there was a small, not significant increase in the sICAM-1 level from 505 (46) $\mathrm{ng} / \mathrm{ml}$ before treatment to $798(295) \mathrm{ng} / \mathrm{ml}$ at six months and $788(295) \mathrm{ng} / \mathrm{ml}$ at the end of treatment (Fig 4).

Serum HCV-RNA became undetectable after one year's treatment with IFN- $\alpha$ in five of 10 responders, but in none of the six who did not respond $(p=0.05)$. At the end of one year of interferon treatment, two out of 10 responders remained viraemic as opposed to five of six non-responders $(p=0.02)$. HCV-RNA was detected intermittently in two of the patients who responded to treatment and in one who did not and in the remaining patient, who responded to IFN- $\alpha$, serum HCV RNA was undetectable throughout the study (Table II). Liver histology showed reduced inflammatory infiltrates in the lobular and periportal areas in responders; in none of the patients was there a change in histological grading, and in two patients the degree of fibrosis had progressed.

Serum ICAM-1 levels continued to reflect the response to interferon therapy in the patients studied one year after the end of

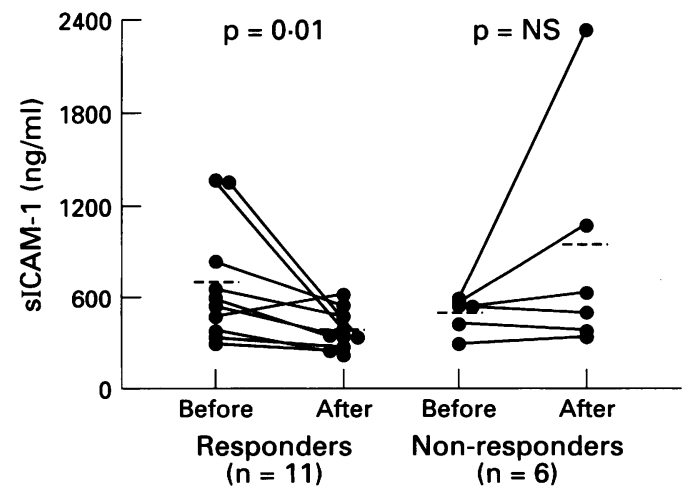

Figure 4: The effect of interferon- $\alpha$ treatment (at the end of one year) on serum intercellular adhesion molecule-1 (ICAM-1) values ( $\mathrm{ng} / \mathrm{ml})$. Bars indicate mean sICAM-1 levels.

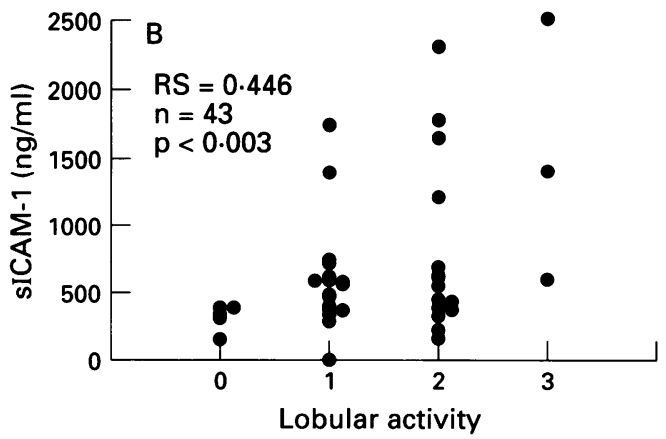

Figure 3: Correlation between serum intercellular adhesion molecule-1 (ICAM-1) ( $\mathrm{ng} / \mathrm{ml})$ and portal inflammation $(A)$, lobular activities (B), and aspartate transaminase activities (AST) (IU/) (C).

treatment. Six of the seven responders had normal transaminase activities, whereas all six non-responders had persistently high transaminase values $(p=0.004)$. The SICAM-1 levels followed a similar pattern to aspartate transaminase, being $375(51) \mathrm{ng} / \mathrm{ml}$ in responders and 892 (397) $\mathrm{ng} / \mathrm{ml}$ in non-responders one year after treatment (Fig 5). A continued histological improvement was seen in the responder group, with a further reduction in inflammation, although some progression of fibrosis was observed in two of the 10 patients who underwent biopsy at one year. Patients who subsequently relapsed tended to have higher levels of sICAM at the end of treatment than those with a lasting response.

\section{Discussion}

In this study serum ICAM-1 levels were increased in patients with chronic $\mathrm{HCV}$ and this elevation correlated with serum aspartate transaminase activities, portal/periportal inflammation, and lobular disease activity. The increase of SICAM-1 may be explained by cytokine induced up-regulation of ICAM-1 expression by leukocyte infiltrates and release from inflamed hepatocytes or damaged vascular endothelium within the liver as well as peripheral blood mononuclear cells (PBMC). Thus far, it has been assumed that ICAM-1 detected in the serum originated from PBMC. In a recent study by Thomson et al using reverse transcriptase polymerase chain reaction, ICAM-1 gene expression of PBMC was

TABLE II The effect of interferon- $\alpha 2 B$ treatment on serum hepatitis $C$ virus (HCV) RNA in patients with chronic $H C V$ infection

\begin{tabular}{llllll}
\hline & \multicolumn{4}{l}{$H C V N N A$} & \\
\cline { 2 - 5 } & $\begin{array}{l}\text { Pre } \\
+v e\end{array}$ & $\begin{array}{l}\text { Post } \\
\text {-ve }\end{array}$ & $\begin{array}{l}\text { Pre } \\
\text { +ve }\end{array}$ & $\begin{array}{l}\text { Post } \\
\text {-ve }\end{array}$ & $\begin{array}{l}\text { No clear } \\
\text { pattern }\end{array}$ \\
\hline Responders $(\mathrm{n}=10)$ & 5 & 2 & 3 \\
Non-responders $(\mathrm{n}=6)$ & 0 & 5 & 1 \\
\hline
\end{tabular}




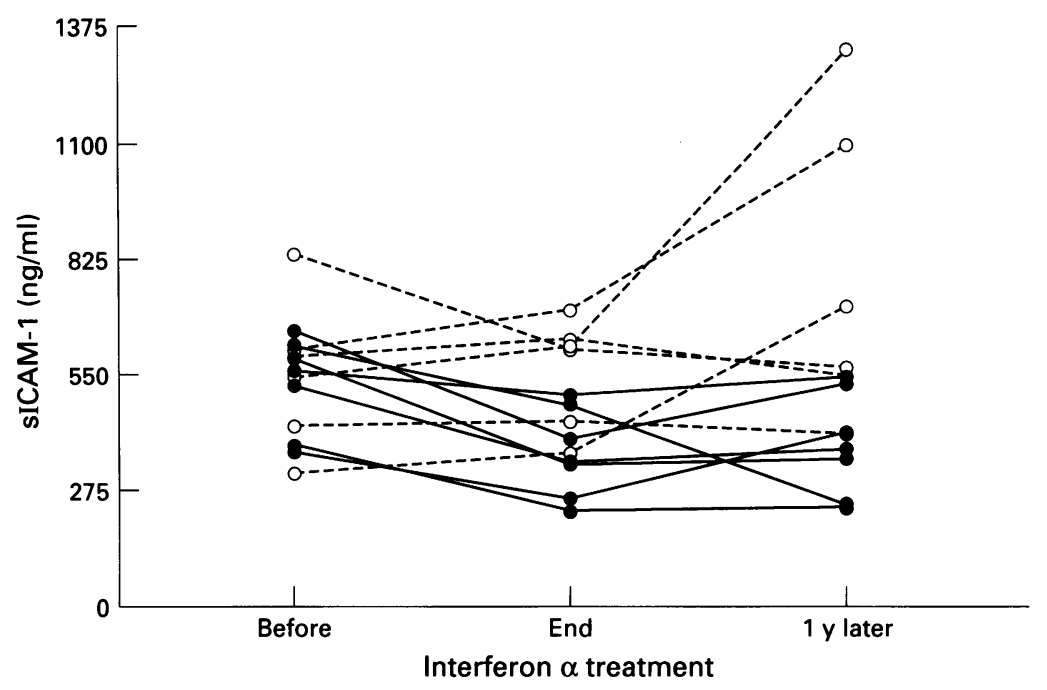

Figure 5: Serial studies of the effects of interferon- $\alpha$ treatment (at the end of one year) on serum intercellular adhesion molecule-1 (ICAM-1) values $(\mathrm{ng} / \mathrm{ml})$. ( $\bullet$ responders, o non-responders). cules in both chronic hepatitis B and C. ${ }^{22}$ Enhanced hepatocyte expression ICAM-1 in areas of periportal and lobular inflammation decreased or completely disappeared in patients who responded to IFN- $\alpha$ treatment. The continued increase in sICAM-1 in responders to treatment, in spite of normal transaminase activities, reflects continued lobular and periportal inflammation on biopsy tissue, indicating that it is the inflammatory process rather than hepatocyte necrosis that is responsible for increased levels. sICAM may therefore provide a potential, non-invasive indication of hepatic inflammatory activity. The mechanisms by which effective IFN- $\alpha$ treatment may reduce ICAM-1 levels is open to speculation. The reduced levels may simply reflect the antiviral effects of IFN in protecting hepatocytes from the direct cytopathic effect of $H C V$. Alternatively, IFN- $\alpha$ may modify the function of cells responsible for production of several proinflammatory soluble factors, by switching off cytokine gene expression in cells present either in circulation or at the site of hepatic injury, resulting in the down regulation of ICAM-1 synthesis.

The identification of SICAM-1 as a marker of histological and immunological changes in response to interferon therapy in chronic $\mathrm{HCV}$ infection is of importance as there is no other test accurately reflecting hepatic inflammatory changes that can be used to monitor the effectiveness of such therapy. Although a fall in serum HCV-RNA can be used as a marker of interferon response, this does not always reflect histological findings and is not correlated with the aspartate transaminase activity. It is to be stressed, however, that it is only in the context of serial levels that sICAM-1 measurement is of value, as absolute levels vary from patient to patient. ${ }^{23}$

We are indebted to Schering Plough for their generous support. sICAM-1 levels in our study would be in favour of cells within the liver rather than in the periphery being responsible for the release of ICAM-1 into the serum, although the contribution of the latter cannot be excluded. It is also possible that ICAM-1 found in the serum may result from a non-specific proteolytic cleavage of membrane ICAM-1 expressed on various cells within the inflamed liver or from alternative splicing of mRNA which deletes the cytoplasmic and trans-membrane domains of the molecule. ${ }^{6}$ Our results are consistent with recent studies by Adams et al and Zohrens et al, who reported increases in serum ICAM-1 levels in patients with various types of liver disease, and correlations between sICAM-1 levels, serum aspartate transaminase activities, histologically graded disease activity, and the response to immunosuppressive treatment in patients with autoimmune chronic active hepatitis. ${ }^{12} 13$

Our demonstration that a fall in SICAM-1 levels with successful interferon treatment reflects a fall in histological inflammatory activity concurs with data published recently by Garcia-Monzon et al on hepatic expression of ICAM-1. They reported that effective IFN$\alpha$ treatment seems to be associated with the down-regulation of hepatic adhesion mole-
1 Springer TA. Adhesion receptors of the immune system. Nature 1990; 346: 425-34

2 Staunton DE, Marlin SD, Stratowa C, Dustin MI Springer TA. Primary structure of intercellular adhesion molecule 1 (ICAM-1) demonstrates interaction between members of the Ig and integrin supergene families. Cell 1988; 52: 925-33.

3 Diamond MS, Staunton DE, DeFougerolles AR, Stacker SA, Garcia-Aguilar J, Hibbs ML, et al. ICAM-1 (CD54): A counter-receptor for Mac-1 (CD1 1b/CD18). F Cell Biol 1990; 111: 3129-39.

4 Makgoba MW, Sanders ME, Luce GEG, Gugel EA, Dustin ML, Springer TA, et al. Functional evidence that ICAM1 is a ligand for LFA-1 in cytotoxic T cell recognition. Eur I Immunol 1988; 18: 637-40.

5 Van Seveneter GA, Shimizu Y, Horgan KI, Shaw S. The LFA-1 ligand ICAM-1 provides an important costimulatory signal for $T$ cell receptor-mediated activation of resting human $T$ cells. F Immunol 1990; 144: 4579-86.

6 Rothlein R, Czajkowski M, O'Neil MM, Marlin SD, Mainolf E, Merluzzi VJ. Induction of intercellular adhesion molecule- 1 on primary and continuous cell lines by pro-inflammatory cytokines. F Immunol 1988; 141: 1665-9.

7 Ayres RCS, Neuberger Jm, Shaw J, Joplin R, Adams DH. In vitro expression of ICAM-1 on biliary epithelial cells fol1993; 34: 1245-9.

8 Rothlein R, Mainolfi EA, Czajkowski M, Marlin SD A form of circulating ICAM- 1 in human serum. $\mathcal{f}$ Immunol 1991; 147: 3788-93.

9 Bahn RS, Heufelder AE. Soluble intercellular adhesion molecule-1 (sICAM-1) in sera of patients with Graves' ophthalmopathy and thyroid diseases. Clin Exp Immunol ophthalmopathy and

10 Seth R, Raymond RD, Makgoba MW. Circulating ICAM-1 immune disorders. Lancet 1991; 338: 83-4. lowing stimulation with TNF- $\alpha$, IL-1 and IFN- $\gamma$. Gut isoforms: diagnostic prospects for inflammatory and 
11 Kojima T, Sasai M, Kobayashi Y. Increased soluble ICAM1 in tracheal aspirates of infants with branchopulmonary dysplasia. Lancet 1993; 342: 1023-4.

12 Adams DH, Mainolfi E, Burra P, Neuberger JM, Ayres R, Elias $\mathrm{E}$, et al. Detection of circulating intercellular adhesion molecule-1 in chronic liver diseases. Hepatology 1992; 16: $810-4$

13 Zohrens G, Armbrust T, Pirzer U, Buschenfelde K-H MZ, Ramadori G. Intercellular adhesion molecule-1 concentration in sera of patients with acute and chronic liver disease: Relationship to disease activity and cirrhosis. Hepatology 1993; 18: 798-802.

14 Nouri-Aria KT, Sallie R, Sangar D, Alexander GJM, Smith H, Byrne J, et al. Detection of genomic and intermediate replicative strands of hepatitis $\mathrm{C}$ virus in liver tissue by in situ hybridisation. $尹$ Clin Invest 1993; 91: tissue by

15 Ulrich PP, Romeo JM, Lane PK, Kelly I, Daniel LJ, Vyas GN. Detection, semiquantitation and genetic variation in hepatitis $C$ virus sequence amplified from the plasma of blood donors with elevated alanine aminotransferase. $\mathcal{f}$ Clin Invest 1990; 86: 1609-14.

16 Kwok S, Higuchi R. Avoiding false positive with PCR. Nature 1989; 339: 237-8.

17 Thomson AW, Satoh S, Nussler AK, Tamura K, Woo J, Gvaler J, Van Thiel DH. Circulating intercellular adhesion molecule-1 (ICAM-1) in autoimmune liver disease and evidence for the production of ICAM-1 by cytokine-stimulated hepatocytes. Clin Exp Immunol 1994; 95: 83-90.

18 Morita M, Watanaba Y, Akaike T. Inflammatory cytokines up-regulate intercellular adhesion molecule-1 expression on primary cultured mouse hepatocytes and T-lymphocyte adhesion. Hepatology 1994; 19: 426-31.

19 Volpes R, Van den Oord JJ, Desmet VJ. Hepatic expression of intercellular adhesion molecule-1 (ICAM-1) in vital hepatitis B. Hepatology 1990; 12: 148-54.

20 Volpes R, Van den Oord JJ, Desmet VJ. Immunohistochemical study of adhesion molecules in liver inflammation. Hepatology 1990; 12: 59-65.

21 Leeuwenberg JFM, Smeets EF, Neefjes JJ, Shaffer MA, Cinek T, Jeunhomme TMAA, et al. E-selectin and intercellular adhesion molecule-1 are released by activated cellular adhesion molecule-1 are released by activated
human endothelial cells in vitro. Immunology 1992; 77: 543-9.

22 Garcia-Monzon C, Garcia-Buey L, Garcia-Sanchez AS, Pajares JM, Moreno-Otero R. Down-regulation of intercellular adhesion molecule 1 on hepatocytes in viral chronic hepatitis treated with interferon alfa-2b. Gastroenterology 1993; 105: 462-9.

23 Gearing AJH, Newman W. Circulating adhesion molecules in disease. Immunology Today 1993; 14: 506-12. 